\title{
TOWARDS THE DEFINITION OF LOGICAL COMPETENCE
}

\author{
$*$ \\ Andrew Schumann \\ Head of the Department of Cognitive Science and Mathematical Modelling, \\ University of Information Technology and Management in Rzeszow, Sucharskiego 2. \\ 35-225 Rzeszów, Poland \\ andrew.schumannagmail.com
}

\begin{abstract}
According to logical psychologism that was popular in the nineteenth century, logic was regarded as a natural ability of human psychology. Consequently, the logical competence as a realization of logic knowledge was treated as one of the innate features of human thinking. Nevertheless, within cognitive science it was experimentally proved that our thinking is not free from cognitive biases and to the same extent our reasoning is not free from logical fallacies. Hence, we are forced to consciously clear the thinking of possible distortions to follow logical norms and to realize the logical competence thereby. In the paper, it is shown that some cognitive biases are observed even at the level of cellular reactions to the environment and then at the level of animal behavior. Therefore not logic, but cognitive biases are a natural (biological) mechanism of human thinking. So, the problem of defining the logical competence arises. In this paper, there are some arguments that the logical competence has once appeared as an especial social practice and it has then been developed for a long time before the first treatises on logic.
\end{abstract}

Keywords: logic, cognitive bias, optical illusion, logical competence, legal hermeneutics 


\section{Introduction}

There may be two general approaches to an explication of logical knowledge: normative and phenomenological. In the normative approach, logical concepts and relationships are regarded as established through a creation of logical norms. This approach began with introducing some logical laws (by Aristotle and Gottfried Wilhelm Leibniz) such as tertium non datur and the principle of sufficient reason and then it was transferred into a qualitatively new level with creating the first axiomatic systems of logic (by Bertrand Russell, David Hilbert and many others logicians of the beginning of the $20^{\text {th }}$ century). The second approach emphasizes descriptions, identifications, and developments of logical structures in existing knowledge systems, for example, in jurisprudence. Nevertheless, even an explication of logic in the light of the phenomenological approach may have a normative character, too - such a way was implemented, for example, by E.V. Bulygin in his analysis of logical relations in legal discourse (Al'churron \& Bulygin, 2013).

This paper examines the nature of logical knowledge within the normative approach, namely, logic is presented as a logical competence - the normalized ability to build consistent conclusions, applying certain inference rules. As a result of such an analysis, it is possible to determine the very boundaries of the normalization of logical knowledge as such. Within the framework of this consideration, the logical competence is understood, first of all, as a social mechanism of cognition within the framework of common human ways of finding a consensus.

In the every-day life of people, the logical competence is detected only with some biased forms (Tverky \& Kahneman, 1974). This raises problems how far logic or logical competence can be considered an innate ability of humans. In the $19^{\text {th }}$ century it was maintained (within the logical psychologism), see (Heymans, 1905), that logic gives some limits of our thinking and, therefore, is absolutely natural for us, because it is a part of our psychology. In this paper, I'll show that logic is ever biased not only in our reasoning, but also in biological processes of transmitting signals from the external world, and it can be biased more or less, but its pure (unbiased) forms are almost impossible. So, the logical competence is not natural and it arises as a special social practice of finding different forms of consensus among humans. In Section 2, the logical psychologism presenting logic as an innate human ability is sharply criticized. In Section 3, it is shown that biased and unbiased forms of reasoning are studied together in informal logic or argumentation theory. In Section 4, on the basis of intra- and inter-cellular effects caused by a lateral activation and a lateral inhibition, it is demonstrated that each cell receives signals most often through some "biases". Let us note that the lateral activation can be treated as a state of satisfaction on the microlevel, while the lateral inhibition as a state of stress. In Section 5, there are regarded some biased ways 
of intelligent reactions performed by different animals to show that these reactions repeat the lateral activation and the lateral inhibition, but now on the macrolevel. In Section 6, it is shown the that logical competence without some biased manifestations can be realized only as a special social practice among humans and this practice was first formed within the Sumero-Akkadian legal tradition and only then it was reflected within philosophy.

\section{Logical Psychologism and its Criticism}

Due to some experimental data of cognitive science (Tverky \& Kahneman, 1974), it became known that logic is not an innate ability of humans and it can be cultivated only in the process of learning and practical applications. Accordingly, the use of logical competence in legal discourse or other human areas does not occur by itself, but it is possible only through a direct constitution of some norms.

In the $19^{\text {th }}$ century, there was another general understanding of logical competence, according to which this competence was considered an integral part of human thinking and cognition, and logic itself with all the laws was reduced to psychology and its laws. This approach to the logical competence (in the light of justifying the reducibility of logic to psychology) is called logical psychologism. According to it, the logical competence as a whole is natural for human cognition (Heymans, 1905). The development of logic is just the development of reflection on the already existing forms of logical thinking.

The logical psychologism has its roots in traditional definitions of logic as a natural way of thinking, e.g. in this manner logic is defined by Antoine Arnauld (1612 - 1694) and Pierre Nicole (1625 - 1695):

La logique est l'art de bien conduire sa raison dans la connaissance des choses, tant pour s'instruire soi-même que pour en instruire les autres.

Cet art consiste dans les réflexions que les hommes ont faites sur les quatre principales opérations de leur esprit, concevoir, juger, raisonner et ordonner (Arnauld \& Nicole, 1662/1992, p. 30).

Logic is an art of leading one's reason well to the knowledge of things, both to educate oneself and to instruct others.

This art consists of the reflections that men have made on the four main operations of their mind: representation, judgement, entailment, and ordering.

This understanding of logic was common for logic handbooks written from the $19^{\text {th }}$ century to the early $20^{\text {th }}$ century: logic is "a science of the laws of correct thinking" (Chelpanov, 1917 , p. 1). The point is that logic gives general frameworks of our knowledge: 
Logic can do nothing but bring to our knowledge the conditions under which this subjective feeling of necessity arises, and express them in a general form (von Sigwart, 1895, p. 15).

Our cognitions are possible only due to logic:

Logic is a science of the methods of thinking, with the help of which the human mind seeks to achieve the knowledge of existence (Povarnin, 1916, p. 3).

Logic is a science that shows how thinking should be done in order for truth to be achieved (Chelpanov, 1917, p. 1).

There are several laws of our cognition (first of all, the principle of identity, the law of contradiction, and the law of excluded middle) and several forms of thinking (first of all, concept, judgement, and inference) which are studied in logic:

Logic is the science of the laws and forms of correct constructions of thoughts (Vinogradov \& Kuz'min, 1954, p. 3).

The logical psychologism was preserved in Russian handbooks of logic till now:

The term 'logic' ... is used both to designate a set of rules that manage the process of thinking, reflecting reality, and to designate the science of the rules of reasoning and the forms in which it is carried out. <...> It [A.S.: logic] explores thinking as a means of knowing the objective world, those forms and laws in which the world is reflected in the process of thinking (Getmanova, 2011, p. 11).

Friedrich Ludwig Gottlob Frege (1848 - 1925) was one of the first to offer sharp criticism of logical psychologism and to convincingly show that logic, nevertheless, is completely autonomous from psychology and represents an intersubjective knowledge obtained through the study of methods of compositional combination of meaningful sentences with achieving a conclusion (Frege, 1934). Logic, in the end, is a more general science than mathematics.

According to Frege, logic studies our thinking as drawing conclusions, but it does not study the external world and its representations:

Die Gedanken sind weder Dinge der Außenwelt noch Vorstellungen. Ein drittes Reich muß anerkannt werden. Was zu diesem gehört, stimmt mit den Vorstellungen darin überein, daß es nicht mit den Sinnen wahrgenommen werden kann, mit den Dingen aber darin, daß es keines Trägers bedarf, zu dessen Bewußtseinsinhalte es gehört (Frege, 1918/1919, p. 69). 
Thoughts are neither things of the external world nor representations. A third empire must be recognized. What belongs to this agrees with the idea that it cannot be perceived by the senses, but with things that there is no need for an actor to whose consciousness it belongs.

Frege's approach to the logical competence is now called logicism. According to this approach, mathematics is reducible to logic, and the logical competence itself is understood as an ability to draw correct conclusions based on meaningful sentences chosen as axioms or hypotheses (assumptions). This ability is associated exclusively with a knowledge of inference rules, which give consistent results. These inference rules are formulated within constructing a logical system and can be different. In particular, in the $20^{\text {th }}$ century the so-called non-classical logics arose, which have axioms and inference rules a lot different from those used by the creators of mathematical logic (Gottlob Frege, Bertrand Russell and others), but they also provide consistent knowledge. For example, there are many-valued logics, where the law of excluded middle does not hold true, and paraconsistent logics, where the law of contradiction does not hold true, etc.

Thus, in logic there are no laws - it is just a study of inferences by their formalizations taking into account the fact that these formalizations can be different, because they are acceptable only due to their consistency:

$<\ldots>$ ein neues Feld der Forschung eröffnet, indem die Formalisierung des logischen Schließens zu einer systematischen Beweistheorie verwertet wurde, welche die Frage nach der Tragweite der logischen Schlußweisen, die von der traditionellen Logik nur in einer sehr speziellen Form gestellt und gelöst wurde, in systematischer Allgemeinheit behandelt und durch deren Untersuchungsmethode die Probleme der Grundlagen der Mathematik mit den logischen Problemen in unmittelbaren Zusammenhang treten (Hilbert \& Bernays, 1968, p. 44).

$<\ldots>$ there was opened up a new field of research by utilizing the formalization of logical inference into a systematic theory of proof, which addresses the question of the scope of logical inference, which traditional logic posed and solved only in a very special way, dealt with in a systematic generality and whose investigation method brings the problems of the fundamentals of mathematics into direct connection with the logical problems.

Kurt Friedrich Gödel (1906 - 1978) showed, in turn, the boundaries of logicism and thus justified the autonomy of mathematics from logic (Gödel, 1931). As a consequence, the logical competence is now understood as a unique ability that is not directly related to a mathematical competence. This is the ability, first of all, to automatically draw conclusions, avoiding contradictions. Investigations of this ability began to be called formal logic: 
Our subject is logic - or, as we may say more fully, in order to distinguish from certain topics and doctrines which have (unfortunately) been called by the same name, it is formal logic.

Traditionally, (formal) logic is concerned with the analysis of sentences or of propositions and of proof with attention to the form in abstraction from the matter (Church, 1996, p. 1).

Other names of the study of inferences: theoretical logic (die theoretische Logik), mathematical logic (die mathematische Logik), and symbolic logic (die symbolische Logik), e.g. see (Hilbert \& Ackermann, 1949, p. 1). Now logic as such is understood as this investigation: "Logic is a science that studies principles and methods of inference" (Mortari, 2001, p. 2); "Logic is the study of the methods and standards of inference" (Kelley, 2014, p. 2). On the other hand, logic began to be studied in the context of cognitive science, also (Stenning \& van Lambalgen 2011, Stenning \& Lambalgen 2008).

\section{Cognitive Biases and Informal Logic}

From the new understanding of logical competence as an ability to mechanically draw consistent conclusions, some plans arose to create artificial intelligence - abstract machines (such as Alan Turing's machines), which themselves are able, based on the data received at the input of the system, to give new data (like conclusions) at the output from the system so that these new data contain already a new knowledge in the form of processing the received data according to the required algorithms. By the beginning of the $21^{\text {st }}$ century significant successes have been achieved in the creation of artificial intelligence systems, which have led to a series of information revolutions.

However, in the form of understanding the logical competence in computer science, it is no longer a natural ability of thinking - neither of animals nor of humans. It is presented exclusively in the implementation of electronic devices, where there is information at the input as well as algorithms that transform it to obtain information at the output. Moreover, these algorithms are taken from classical mathematics with the assumption that all actions in them are sequential and deterministic.

At the beginning of the $21^{\text {st }}$ century, in computer science, a new direction has emerged, called unconventional computing, which studies the possibility of representing any complex natural process (mechanical, chemical, biological) as a specific system of logical (or, more generally, arithmetic) functions (Adamatzky, 2017). For instance, it was shown that Physarum polycephalum, the unicellular organism behaving as a giant amoeba, can approximate some simple algorithms of Kolmogorov-Uspensky machines 
(Adamatzky, 2007) or algorithms of cellular automata (Shirakawa et al., 2015). This amoeba can be examined even as some biological logic gates (Adamatzky \& Schubert, 2014; Jones \& Adamatzky, 2010, Mayne \& Adamatzky, 2015; Schumann, 2015; Whiting et al., 2014). Then these results were generalized to demonstrate that some proteins of amoeboid organisms are responsible for their intelligent behavior. Therefore these proteins can be considered a medium implementing different logical and arithmetic functions. So, some networks of these proteins such as actin filament networks can be presented as a logic or computation medium, too (Adamatzky \& Mayne, 2015; AlonsoSanz \& Adamatzky, 2016; Schumann, 2016, 2017; Siccardi \& Adamatzky, 2015, 2016; Siccardi et al., 2016). Hence, these studies of actin filament networks and behaviors of unicellular organisms are being carried out in order to find out what specific logical and mathematical problems can be encoded in the biochemical processes of living organisms, thus presenting the organisms themselves in the form of computers - in other words, "the logical competence" of unicellular beings is studied (Schumann, 2018). One of the important results of these studies is that noticeable cognitive distortions were shown in the process of receiving signals by the single-celled organisms with subsequent reactions of the organisms to them. It turns out that cognitive distortions and violations of the rules of logic are a natural and integral part of cognition already at the level of behavior of unicellular organisms. Their "logical competence" is not perfect the way computers "think" is significantly different (Schumann, 2018, 2019; Shirakawa et al., 2020).

We can show, therefore, that logic is implemented biologically only in some biased forms. A pure logic does not exist in nature. As we remember, in the philosophy of the $19^{\text {th }}$ century, the idea that logic is a natural way of thinking for all humans was dominant within the logical psychologism. Nevertheless, in the $20^{\text {th }}$ century it was proved experimentally that humans do not think logically in its strict sense surely - their logical competence is imperfect. They make gross blunders even at the primary level of logic. For example, the logical conjunction $A \& B$ is often understood not correctly - some referents do not know that its probability $P(A \& B)$ must be always smaller than the individual probability $P(A)$ or $P(B)$ (Tversky \& Kahneman, 2008). It is an insensitive blunder in understanding conjunction as one of the basic logical operations.

Let $\vdash$ be a sign of logical deducibility. So, $A \vdash B$ means that from $A$ we can deduce $B$, i.e. $A$ is a premise for inferring $B$, and $\vdash B$ means that $B$ is an axiom, i.e. it holds without premises. Then any inference of $A$ from $B$ in classical logic: $A \vdash B$, assumes that an appropriate implication $A \Rightarrow B$ holds. This statement is called the deduction theorem: if $A \vdash B$, then $\vdash A \Rightarrow B$.

In classical logic there are the following two basic inference rules: 
- modus ponens: If $A \Rightarrow B$ and $A$, then $B$ (it means that from the true implication $A \Rightarrow B$ and the true statement $A$ we can infer that $B$ is true, also);

- modus tollens: If $A \Rightarrow B$ and $\neg B$, then $\neg A$ (it means that from the true implication $A \Rightarrow B$ and the true negation of $B$ we can infer the true negation of $A$, as well).

These inference rules are always valid. There are similar deductions which are invalid in fact:

- affirmation of the consequent: If $A \Rightarrow B$ and $B$, then $A$ (but it is invalid that from the true implication $A \Rightarrow B$ and the confirmation of its consequent $B$ we can infer that $A$ is true);

- denial of the antecedent: If $A \Rightarrow B$ and $\neg A$, then $\neg B$ (but it is invalid that from the true implication $A \Rightarrow B$ and the denial of its antecedent $A$ we can infer the denial of its consequent $B$ ).

Understanding that modus ponens and modus tollens are valid, while the affirmation of the consequent and the denial of the antecedent are invalid, constitute the nuts and bolts of elementary propositional logic. Without this understanding any reasoning will contain fallacies. But it turned out that sometimes even the scientists cannot draw elementary correct conclusions from conditionals presented by true implications. So, seventy-two scientists including psychologists, biologists, and physicists from a large US university completed a questionnaire (Kern et al., 1983) to check their abilities to rate the validity of four forms of propositional inference: modus ponens, modus tollens, affirmation of the consequent, and denial of the antecedent. As a result, some of them made serious fallacies, see Table 1. In the meanwhile, there was detected the failure of nearly half of the scientists to recognize the logical validity of modus tollens, one of the two fundamental inference rules of propositional logic. This experiment shows that even the scientists do not think purely logically with avoiding unintentional fallacies.

Table 1.

This table shows that the scientists make gross fallacies in understanding modus ponens, modus tollens, affirming the consequent, denying the antecedent. Even the logic training for them is not so helpful. The table is taken from the work of L.H. Kern, H.L. Mirels, V.G. Hinshaw (1983). 


\begin{tabular}{|c|c|c|c|c|c|}
\hline REFERENTS & PSYCHOLOGISTS & BIOLOGISTS & PHYSICISTS & $\begin{array}{c}\text { OVERALL } \\
\text { PERCENTAGE } \\
\text { ACROSS } \\
\text { DISCIPLINES (NO } \\
\text { LOGIC TRAINING) }\end{array}$ & $\begin{array}{c}\text { SOME LOGIC } \\
\text { TRAINING (N }=26)\end{array}$ \\
\hline $\begin{array}{l}\text { 1. Recognizing } \\
\text { the logical validity } \\
\text { of modus ponens, }\end{array}$ & $91.5 \%$ & $96 \%$ & $96 \%$ & $94.5 \%$ & $100 \%$ \\
\hline abstract scheme: & $83 \%$ & $92 \%$ & $92 \%$ & $89 \%$ & $100 \%$ \\
\hline concrete example: & $100 \%$ & $100 \%$ & $100 \%$ & $100 \%$ & $100 \%$ \\
\hline $\begin{array}{l}\text { 2. Recognizing } \\
\text { the logical } \\
\text { invalidity of denial } \\
\text { of the antecedent, }\end{array}$ & $79 \%$ & $66.5 \%$ & $87.5 \%$ & $77.5 \%$ & $83.5 \%$ \\
\hline abstract scheme: & $83 \%$ & $58 \%$ & $75 \%$ & $72 \%$ & $67 \%$ \\
\hline concrete example: & $75 \%$ & $75 \%$ & $100 \%$ & $83 \%$ & $100 \%$ \\
\hline $\begin{array}{l}\text { 3. Recognizing } \\
\text { the logical invalidi- } \\
\text { ty of affirmation of } \\
\text { the consequent, }\end{array}$ & $79 \%$ & $62.5 \%$ & $83.5 \%$ & $72.5 \%$ & $84.5 \%$ \\
\hline abstract scheme: & $83 \%$ & $75 \%$ & $75 \%$ & $73 \%$ & $87 \%$ \\
\hline concrete example: & $75 \%$ & $50 \%$ & $92 \%$ & $72 \%$ & $82 \%$ \\
\hline $\begin{array}{l}\text { 4. Recognizing } \\
\text { the logical validity } \\
\text { of modus tollens, }\end{array}$ & $41.5 \%$ & $58 \%$ & $66.5 \%$ & $55 \%$ & $72 \%$ \\
\hline abstract scheme: & $33 \%$ & $33 \%$ & $58 \%$ & $41 \%$ & $53 \%$ \\
\hline concrete example: & $50 \%$ & $83 \%$ & $75 \%$ & $69 \%$ & $91 \%$ \\
\hline
\end{tabular}


As it was shown (Sjoberg, 2017), the fallacy of affirming the consequent is very common for biologists. Sometimes they recognize the following reasoning as logically valid: "If bipolar patients have reduced cognitive processing speed, then we will observe slower reaction time on a test. We observe a slower reaction time, and therefore bipolar patients have reduced cognitive processing speed". Furthermore, they often use the false analogy to extrapolate from sharing some characteristics between two groups of animals to sharing their other characteristics (Sjoberg, 2017).

Our reasoning with its biased forms is studied in two modern logical disciplines: critical thinking and informal logic (or argumentation theory). So, critical thinking is examined as an ability to detect cognitive biases to avoid them (Baker, 2020) and informal logic is defined as a science that studies both biased and unbiased inferences:

Logic $\ldots$ is the branch of philosophy that studies the reasoning process and seeks to understand the differences between good and bad reasoning (Crews-Anderson, 2007, p. 8).

Logic is the study of the methods and principles used to distinguish correct from incorrect reasoning (Copi et al., 2014, p. 2).

Thus, logic is not natural even for humans and even for scientists and we study it to avoid some biased inferences. We can then wondered if we can expect to see a pure logic in nature - how far biological processes of Physarum polycephalum or actin filament networks can implement the pure logic.

\section{Explaining Optical Illusions due to the Lateral Inhibition and the Lateral Activation}

We may observe the following fundamental duality in all active reactions of different organisms to external stimuli: each stimulus either attracts the organism or repels it. So, each stimulus which changes the behavior of individuals in fact, can be considered either an attractant (such as food pieces or sex pheromone) or a repellent (such as predators or poisons). This duality is topological: the attractant can be occupied from different directions, but from the repellent each individual moves in different directions (Shirakawa et al., 2012; Fackler \& Grosse, 2008; Pollard \& Borisy, 2003; Van Haastert \& Devreotes, 2004). On the basis of this topological duality, it is possible to present (i) the attractants $|p|,|q|$, $\ldots,|r|$, occupied by some individuals, as true propositional variables $p, q, \ldots, r$; (ii) and the repellents $|\dot{p}|,|\dot{q}|, \ldots,|\dot{r}|$, avoided by some individuals, as true negations $\neg p, \neg q, \ldots, \neg r$.

Evidently, different attractants (repellents) have a different intensity of their influence on individual behaviors: they can more or less attract (repel) organisms. This property can be 
expressed by a degree of truth (falsehood) presented by the interval of real numbers [0, 1], where it is possible to be closer to 0 (it means, do more to repel) or to 1 (do more to attract).

Now, let us consider several attractants $|p|,|q|, \ldots,|r|$ and several repellents $|\dot{p}|,|\dot{q}|, \ldots$, $|\dot{r}|$. Surely that all the repellents $|\dot{p}|,|\dot{q}|, \ldots,|\dot{r}|$ must be avoided. Then this reaction of individuals can be treated as the following true conjunction: $\neg p \& \neg q \& \ldots \& \neg r$ (it means $|\dot{p}|,|\dot{q}|, \ldots,|\dot{r}|$ are avoided simultaneously). However, in respect to the attractants $|p|,|q|$, $\ldots,|r|$ reactions of individuals can be very different. First of all, there are the following two typical reactions: (i) fusion as an attempt of focusing only on one attractant (or on a small number of attractants) to occupy it (them) first and foremost; (ii) splitting as an attempt of occupying several attractants at once, the more the better.

Both possible reactions to the attractants are explained by the following two complementary mechanisms in perceiving signals on the intra- and inter-cellular levels: (i) a lateral inhibition corresponding to a fusion, it expresses some stress conditions which increase the contrast of one signal to react more directly and efficiently and to be better focused; (ii) a lateral activation corresponding to a splitting, it shows some comfortable conditions which decrease the contrast of signals to perform concurrent actions (Jones, 2015; Schumann \& Kuznetsov, 2018). These mechanisms in perceiving stimuli are scale-invariant. First, they occur during assembling and disassembling of actin filament waves to cause a fusion of protoplasmic tubes of Physarum polycephalum or splitting them. Second, they occur between groups of neurons within the visual cortex to process visual cues more or less focused. Third, they occur between active zones of swarms to react to their environments to occupy attractants more or less focused, too.

Repellents $|\dot{p}|,|\dot{q}|, \ldots,|\dot{r}|$ cause always a stress in individuals, therefore each individual tries to be concentrated on the repellents due to the lateral inhibition to avoid all of them in advance. But for attractants $|p|,|q|, \ldots,|r|$ each individual can be more laterally inhibited or more laterally activated. As a consequence, it starts to occupy all attractants or only some of them. The attractants in focus are connected by conjunction. The attractants which are not in focus are connected by disjunction. Hence, the lateral inhibition for signals $|p|, \mid$ $q|, \ldots| r \mid$, gives their increasing $p \& q \& \ldots \& r$, while the lateral activation for signals $\mid p$ $|| q,|, \ldots| r \mid$, gives their decreasing $p \vee q \vee \ldots \vee r$. The problem is that there is a smooth transformation between lateral inhibition and lateral activation. Therefore, there is the same smooth transformation between conjunction and disjunction which is difficult to be presented logically. In other words, conjunction as well as disjunction can be more or less biased (activated).

Many optical illusions occur, because our brain is trained to switch between lateral inhibition and lateral activation automatically under different conditions. For example, in 
the Müller-Lyer illusion, see Fig.1, we perceive a length of a line depending on whether the line has the inward wings, see Fig.1(a) (when we follow the lateral inhibition effect), or the outward wings, see Fig.1(b) (the lateral activation effect). It is worth noting that T. Sakiyama and Y.-P. Gunji (2013) showed that the Müller-Lyer illusion holds for the group behavior of foraging ants. They explain this phenomenon by that each swarm of ants has the following two main logistic tasks: (i) to build a global route system connecting the nest with food sources to monopolize all reachable food sources (it corresponds to the lateral activation, that is, to the colony's ability to discover new food sources through exploration); (ii) to exploit effectively and efficiently each found food source (it corresponds to the lateral inhibition, i.e. to the colony's ability to concentrate on some food sources).

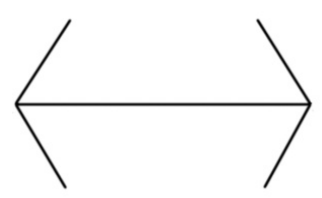

(a) Line with inward wings.

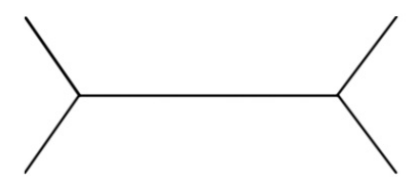

(b) Line with outward wings.

(c) Line without wings.

Figure 1. The Müller-Lyer illusion. The lines of (a), (b), (c) are of the same length. Nevertheless, it seems to us that the line with the inward wings (i.e. (a)) is shorter than line (b), and the line with the outward wings (i.e. (b)) is longer than line (a). 
In the Ebbinghaus illusion, see Fig.2, as well as in the Delboeuf illusion, see Fig.3, perceiving the disc surrounded by bigger figures is laterally inhibited, therefore this disc seems to be smaller, while perceiving the disc surrounded by smaller figures is laterally activated, therefore this disc seems to be larger. It was shown (Howard et al., 2017) that a kind of Ebbinghaus or Delboeuf illusions can be observed in the behavioral patterns of honeybees. So, when the viewing distance was unrestricted, an appropriate illusion occurred. However, when the viewing distance was restricted, bees did not demonstrate perceiving the Ebbinghaus or Delboeuf illusions.

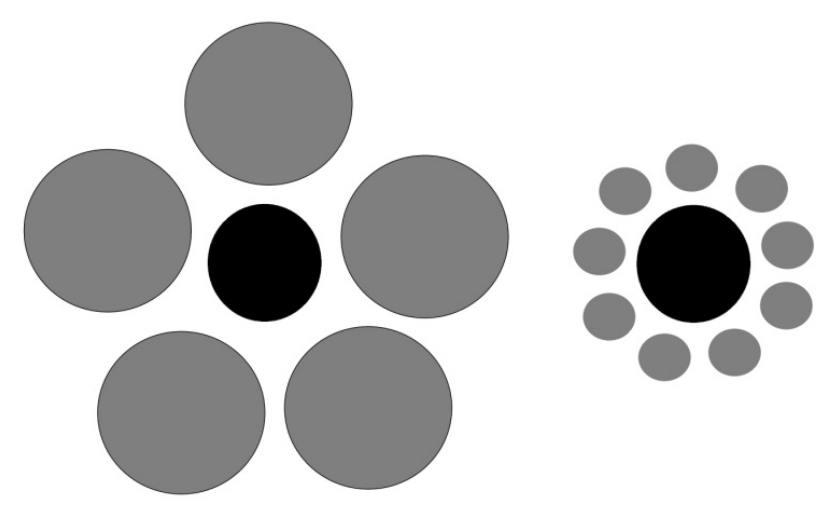

Figure 2. The Ebbinghaus illusion. The two discs in both centers are of the same size, but the right one seems to be larger than the left one because of the surrounded discs of different diameters.
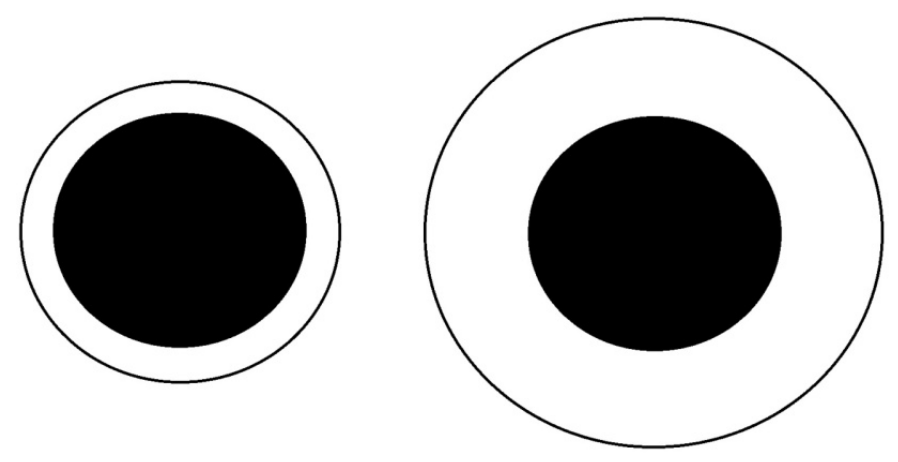

Figure 3. The Delboeuf illusion. The two discs in both centers are of identical size, but the left one seems to be larger than the right one because of the surrounded rings of different diameters.

Note that at least one Grey parrot (Psittacus erithacus) reports the Müller-Lyer illusion under certain conditions (Pepperberg et al., 2008). The Ebbinghaus and Delboeuf illusions are well traced in perceptions of macaque monkeys and some other species of monkeys (Parrish et al., 2015; Huang et al., 2002). The point is that the perception of brightness in macaques and humans is quite similar because of common underlying neural computations in the two 
species. The same illusions under some conditions are well traced in perceptions of red-footed tortoises (Chelonoidis carbonaria) and bearded dragons (Pogona vitticeps) (Santacà et al., 2019). Nevertheless, they are not so well reported for domestic dogs (Byosiere et al., 2020). Thus, different mechanisms of lateral inhibition and activation may alter perceiving or not perceiving different illusions in a particular species. This data could improve our understanding of animal perception. In any case this perception is always biased. So, a reaction of any organism to stimuli can be more conjunctive (laterally inhibited) or more disjunctive (laterally activated) than it is in fact.

Hence, the negation as a logical operation has its biological meaning presented as appropriate responses to repellent stimuli. The conjunction as a logical operation may be biologically treated as laterally inhibited responses to several stimuli at once. The disjunction as a logical operation may be understood as laterally activated responses to several stimuli simultaneously. This allows us to implement some logic gates within the biological reactions (Whiting et al., 2014, Schumann \& Pancerz, 2019). But the problem is that these implementations can be realized only with strict limits and strong approximations. The matter is that the negation, conjunction, and disjunction are some pure ideal forms which are unchangeable, while repelling, lateral inhibition, and lateral activation are instable and exist only in some hybrid forms with being more inhibited or activated or being a mixture of those reactions. And that is why the lateral inhibition and lateral activation are more responsible for biases and cognitive distortions than for purely logical reactions.

\section{Cognitive Biases of Humans and Animals}

Behavioral scenarios of human and animals may be more or less rational - as an attempt to maximize own profits. If they are at least partly irrational (i.e. there are no forecasted maximal profits after carrying out these scenarios), they are called cognitive biases or distortions. There are the same two main reasons of many biases: stress as psychic reaction (analogous to the lateral inhibition with one neural network) and satisfaction (analogous to the lateral activation of neurons). For example, managers usually overestimate the probability of positive forecasting (Heaton, 2002) - they are not focused enough (i.e. not enough laterally inhibited - in the terms of neural networks) and pay more attention to information that supports their opinions. Among cognitive biases of managers there are the so-called framing (when they may frame the risky outcome differently, either considering the worst case or the best case) and confidence (their optimistic or pessimistic assessment of one's ability to perform, e.g. in a period of economic recession, people are less confident and more pessimistic about future economic conditions and, as a consequence, they avoid risky decisions) (Chen et al., 2001). There is also a 'herd behavior', when they copy actions of a 
larger group due to the social pressure of conformity, e.g. some investors may follow others to buy the same stocks (Gilovich et al., 2002). The study of different cognitive biases and their influences on making financial decisions is presented in behavioral finance (Goldberg \& von Nitzch, 2001), a new approach in finance studying some real irrational patterns of decision-making. So, managers are not enough logical and their decisions are at least partly always biased - through a stress or satisfaction.

Now, cognitive biases and distortions are studied for animals, too, first of all for animals of zoo and aquaria to check their affective states to know whether their welfare is acceptable or it should be improved (Cleggm 2018). It is stated (Spruijt et al., 2001) that a balance of positive and negative affective states is always preferable for managing zoo or aquaria. For instance, cognitive biases are analysed for bottlenose dolphins (Tursiops truncatus) (Clegg et al., 2017) and western lowland gorillas (Gorilla gorilla gorilla) (Daoudi et al., 2017). It is learnt that under stress conditions animals follow more pessimistic judgements about ambiguous stimuli, pay more attention to negative stimuli, and remember more often negative memories (Clegg 2018; Eysenck et al., 1991; Wright \& Bower, 1992). As a consequence, it was detected (Robinson \& Roiser, 2016) that, similar to humans, animals in their negative affective states exhibit negative affective biases on decision-making and memory tasks. Their emotional responses to a stimulus can be quick, but at the same time there are affective states which are longer (such as anxiety or depression) and they are not caused by a single stimulus but are the results of their experiences (Robinson \& Roiser, 2016). There was developed a special system of judgment bias tasks (Roelofs et al., 2016) to assess emotional states of animals by a cognitive measure of their optimism and/or pessimism by recording behavioral responses to ambiguous stimuli.

Hence, cognitive biases are normal mechanisms of thinking not only of humans, but also of animals. People, like animals, do not think purely logically, which means that their logical competence, by definition, is far from perfect. At the same time, there are two main affects in decision-making (i.e. in building an inference): stress and pleasure. At the micro level, both affects are expressed by two mechanisms in the perception of signals: lateral inhibition (analogue of stress) and lateral activation (analogue of satisfaction).

Different forms of cognitive distortions in our reasoning are called logical fallacies. They are not directly related to stress and satisfaction as two essential moods of our emotions. Among them there are 'motivational biases' which reflect a desire, involved in inferences, to achieve a result in discussions. Usually, these biases are committed unintentionally (Correia, 2011). The matter is that "people are more likely to arrive at conclusions that they want to arrive at, but their ability to do so is constrained by their ability to construct seemingly reasonable justifications for these conclusions" (Kunda 1990, p. 480). In other words, people 
tend to seem rational - based on some arguments, but they do not know logical norms well. For example, the alcoholic can justify his or her excessive drinking by affirming: "I am not an alcoholic. I drink because..." (Correia, 2011, p. 119). Nevertheless, his or her further reasoning thereby will be imperfect logically. Also, there are as the straw man fallacy presenting a strategy whereby the proponent misrepresents the some intentional fallacies such opponent's position in a way that makes it easier to be refuted, and then refutes this made up position instead of the real one (Talisse \& Aikin, 2006; Johnson \& Blair, 1983; Walton, 1989). In any case each logical fallacy has an appropriate belief biasing the reasoning and an appropriate emotional distortion in accepting logically correct inferences (Cohen, 1992). Furthermore, logical fallacies are rooted in real discussion so that purely logical forms of inferring do not seem to be a real practice in the every-day argumentation (von Eemeren, 1986, Walton 1989).

\section{Logical Competence as a kind of Social Practice}

Within the framework of unconventional computing, the group or swarm behavior of animals is also being explored for their logical competence, namely, the logical competence is discovered in the behavior of so-called 'social' animals (such as bees, ants or horses), which coordinate their behavior among themselves, distributing specific roles from a leader or queen to workers. As a result of these studies, a special direction of unconventional computing arose, called swarm computing (or swarm intelligence) - in it the logical competence is subjected to a logical and mathematical analysis in the form as it is presented in a particular swarm (for example, in an anthill, a nest of bees, a herd of horses, a flock of birds, a school of fish, etc.), see (Bonabeau et al., 1999; Schumann, 2020). Swarms were found to be capable of solving complex logistic problems such as the traveling salesman problem (Dorigo, 1997) or the generalized assignment problem (Ozbakir et al., 2010).

But the swarm behavior is not social in the strict sense of the word - there are no pure conventions consciously shared among the members of the group. From the standpoint of behaviorism, any collective behavior is a complex system that is controlled by stimulating individuals. And in this regard, it would seem that the 'social' behavior of animals is just a simpler stimulation system than the behavior of humans. However, some inevitable cognitive distortions are also recorded in the group behavior of swarm animals, which shows the strict boundaries of behaviorism, its inapplicability in modeling complex forms of group behavior, in which noticeable cognitive distortions are simply inevitable, and, as a consequence, the same combination of stimuli can give different reactions, which contradicts the basic assumptions of behaviorism (Shirakawa et al., 2020; Schumann, 2019). 
In the theory of symbolic interactionism, the creators of which are George Herbert Mead (1863 - 1931) and Herbert Blumer (1900 - 1987), the social behavior is analyzed initially in the light of possible cognitive biases and distortions that are responsible for attributing a special symbolic meaning to some objects when these items get an added value. The founders of this theory noticed that people act in relation to things based on symbolic, and not direct, meanings of these things. In other words, some cognitive biases involved in the cognition of people are fixed in symbolic meanings shared by others, which, thereby, provide social interactions of people, i.e. interactions beyond the biological behavior. The social behavior is built, therefore, on symbolic interactions, which are simply impossible in the swarm behavior due to the absence of the symbolic meanings as such. It turns out that the social behavior is impossible without a material culture - without some objects that have acquired an additional symbolic meaning, consciously shared by this group of people.

At the same time, in order to stabilize societies, there is a need for a long-term consolidation of symbolic meanings and other conditions of symbolic interactions. This is how social institutions are born with legal support as long-term forms of social contact. As a result, the logical competence acquires a new meaning - it is a form of intersubjective decision-making without cognitive distortions from some existing conventions (social norms, provisions, assumptions), which, in turn, are built on symbolic meanings (cognitive biases involved in the formatting of social space).

Thus, the logical competence of people can be understood in different ways: (1) as an individual mechanism of cognition in combination with cognitive distortions; (2) as a swarm cognition combined with cognitive distortions; (3) as a social cognitive mechanism that can be cleared of natural cognitive biases. This research analyzes the origins and early genesis of logical competence in the third sense.

So, the logical competence of a person as a certain practice of thinking, devoid of logical fallacies, is not an innate ability, since in its natural form it is not separable from cognitive distortions, but is a special social practice of making logically correct decisions, which once arose and was subsequently developed and spread through a direct learning.

The logical competence without distortions is implementable within artificial intelligence that is presented as some useful techniques of human cognitions which are free of cognitive biases in advance. Artificial intelligence now is the study of designing expert systems, which help us to analyze the environments and produce actions which maximize success according to some algorithms. The idea of some machines with drawing conclusions in an automatic way which support us in decision-making and finding consensus is quite old and has been popular since Raymundus Lullius (ca. 1235 - 1315) and Gottfried Wilhelm von Leibniz (1646 - 1716). For instance, Leibniz claimed that his analytic language of reasoning 
based on arithmetic operations (characteristica universalis) offers the unbiased forms of conclusions and, therefore, it can be used for converting the Chinese empire to Christianity, because the characteristica universalis is the best way of finding any consensus including the religious one (Swetz, 2003).

Traditionally, Aristotle is considered the father of logic as a science of unbiased inferences. So, we can suppose that only after him we can trace back some samples of perfect logical competence. But it is not true. There is one tradition that is much older than the Aristotlian logic - it is a Sumerian-Akkadian legal hermeneutics established at least since Ur III (Culbertson, 2009; Schumann 2019, 2020), i.e. about four thousand years ago. Within this hermeneutics, laws were presented as law codes, where each article from the code was formulated as a conditional statement (implication): "If an act of $p$ is conducted, then its actor is sentenced to $q$ ". As a consequence, each court should make a decision in accordance with modus ponens:

Law article from a code: "If $p$, then $q$ ";

Fact-checking at the trial: "There is a fact $p$ ”;

Court decision: "There is a sentence $q$ ".

There are excavated many legal documents written in Sumerian and different dialects of Akkadian: law codes, trial records, contracts, testaments, etc. And their authors possess such a high logical competence with demonstrating the good knowledge of various inference rules: modus ponens, modus tollens, introducing conjunction, introducing disjunction, etc. (Schumann, 2019, 2020). Furthermore, in these documents there are no logical fallacies and we can explicate ten or even more logical steps in inferring. This tradition is unique and has no analogies in other ancient cultures.

Hence, the Sumerian-Akkadian legal hermeneutics has its origin in Mesopotamia and has been expanded later through different empires: Neo-Assyrian, Neo-Babylonian, and Achaemenid, then through Hellenistic states, the Roman Empire, and some partly Hellenized states of Central and South Asia participating in trading networks of the Silk Road, such as the Kushan Empire. Laws from state to state can have been different, but the legal hermeneutics, at the same time, was very similar, i.e. the legal matters were changeable, but the logical forms in making legal decisions on the basis of laws were constant. First this hermeneutics was mainly in Akkadian, then in Aramaic and Greek, and only then in some other official languages of the Silk Road such as Bactrian or Sogdian.

Let us show that marriage contracts composed in Akkadian, Aramaic, Greek, and Bactrian have had the same structure since the Old Babylonian period and, accordingly, 
they have belonged to the same joint legal hermeneutics indeed. Furthermore, it is known that Aramaic legal documents were a continuation of legal tradition in Akkadian. Then Greek became the lingua franca of diplomacy and international trade with many clichés borrowed from the Babylonian jurisprudence.

Marriage contracts were needed for obtaining a legal status of wife and husband in an appropriate society according to the Old Babylonian law codes. For example, in the Code of Eshnunna, $\$ 27-28$, we read:

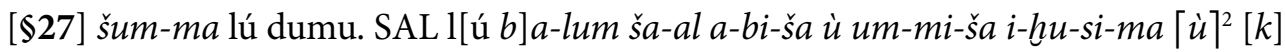

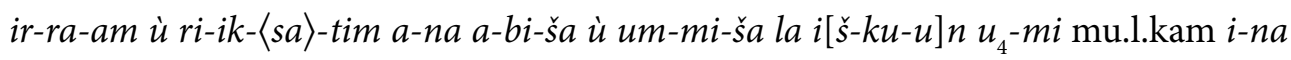
é-šu li-ši-im-ma ú-ul dam

[\$28] šum-ma ul ri-ik-sa-tim ù kir-ra-am a-na a-bi-ša ù um-mi-ša iš-ku-un-ma i-hu-us-si dam $u_{4}$-um ${ }^{4} i$-na su-un lú $\lceil i s ̦-s ̦ a-a b\rceil-b a-t u ~ i-m a-a t ~ u ́-u l ~ i-b a-a l-l u-\lceil u t ̣\rceil$

\$27 If a man took another man's daughter without asking her father and mother and did not arrange for (lit. establish) a libation and marriage contract with her father and mother, though she live in his house for a year, she is not a wife.

$\$ 28$ If ... he arranged for a marriage contract and libation with her father and mother and took her, she is a wife; the day she is caught with (another) man she shall die; she shall not live (Greengus, 1969, p. 505).

More formally:

$\$ 27$ If $r$ (a man and a woman live together) and not $p$ (there is no marriage contract), then not $q$ (she is not a wife).

$\$ 28$ If $p$ (there is a marriage contract), then $q$ (she is a wife). If $q$ (she is a wife) and $s$ (she is caught with another man), then $t$ (she gets death penalty).

The Code of Hammurabi, $\$ 128$, has almost the same article as $₫ 27$ :

[\$128] šum-ma a-wi-lum aš-ša-tam i-hu-uz-ma ri-ik-sa-ti-ša la iš-ku-un SAL ši-i ú-ul $a \check{s}-\check{s} a-a t$

$\$ 128$ If a man took a wife and did not arrange for her marriage contract, that woman is not a wife (Greengus, 1969, p. 505).

Let us assume that there are two facts: not $r$ and $p$, checked at the trial, i.e. a man and a woman do not live together, but they have a marriage contract. Then, according to $\$ 28$ and modus ponens, the court logically infers that $q$, i.e. she is a wife. If we have $r$ and $p$, the court again infers $q$ due to $\$ 28$. Hence, the articles are formulated in the way that allows us 
to apply inference rules of propositional logic to entail legal decisions automatically - for example, to prove that there is a lawful marriage in fact.

Something is treated as a fact in the Sumero-Akkadian hermeneutics only after checking at the trial. To be a fact any state of affairs should be either fixed in a well-composed legal document (past trial decision, contract, will, etc.) or testimonied by at least two witnesses. In legal documents one main thesis as one declarative or a series of declarations (e.g. that the woman is a wife) should be well formulated. Then the declarations are supported by several witnesses who sign (i.e. put their seals on) an appropriate document containing this main thesis. Each additional declarative of the legal document is formulated in the form of implication: "If a state of affair $p$ takes place, then a legal decision $q$ shall be made" so that the next court can use this conditional declarative for making the next decision $q$ just by applying modus ponens after checking the fact of $p$.

Let us quote the marriage contract composed at the time of Erra-Imittī, the ninth king of the first dynasty of Isin who ruled in ca. 1868 - 1861 B.C.:

\section{Obv.}

$\mathbf{1}^{\mathrm{m}}$ reš-tum dumu-munus ur- ${ }^{\mathrm{d}} \mathrm{utu}$

md šu-i-lí-šu

dumu ${ }^{\mathrm{m}} \dot{e}$ r-ra-mu-ba-lí-it

nam-dam-šè in-ni-tuku

5 mu-lugal-ka-ni in-pàd

túg-íb-lá nu-mu-un-zu-[a]-nilin-du

é a-šà ù níg-gur ${ }_{11}$-ra a-na [me-a-bi]

lú-lú-gin 7 al-dím

tukum-bi u $\mathrm{u}_{4}$-kúr-šè

$10{ }^{\mathrm{m}}$ reš-tum ${ }^{\mathrm{md}}{ }^{s ̌ u} u-i$-lí-šu dam-a-ni-éš

dam- $\hat{g}_{10}$ nu-me-en ba-na-an-du ${ }_{11}$

1/2 ma-na kù-babbar ì-lá-e

ù tukum-bi ${ }^{\mathrm{md}} \check{s} u-i-l i ́-\check{s} u$

${ }^{\mathrm{m}}$ reš-tum dam-a-ni-éš

Rev.

15 dam- $\hat{g u}_{10}$ nu-me-en ba- $\langle$ na $\rangle-a n-d u_{11}$

1/2 ma-na kù-babbar ì-lá-e

mu-lugal-bi in-pàd-dè-eš

[igi] ${ }^{\mathrm{m}} n a-b i-{ }^{\mathrm{d}} \mathrm{EN} . Z \mathrm{ZU}$ dumu ${ }^{\mathrm{m}} n a-b i-i-l i ́-s ̌ u$

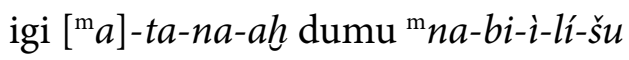


20 igi $a-d u$-ba dumu èr- ${ }^{\mathrm{d} e n-l i ́ l-l a ́ ~}$

igi ${ }^{\mathrm{md}} \mathrm{EN} . Z \mathrm{ZU}-k i-m a-i-l i ́-a$

dumu ${ }^{\mathrm{md}} \mathrm{EN} . Z \mathrm{ZU}-m u-b a-l i-i t$

igi ${ }^{\mathrm{m}} a$-ad-da-wa-qar [dumu xx]-lí-wa-qar

igi ${ }^{\mathrm{m}} a ̀ m-m a-n u-u m$ [lú]-nar

25 igi ${ }^{\mathrm{md}} \mathrm{EN} . Z U-i-d i n-n a-s ̌ u$ DUMU la-bi-šu

iti giš-apin- $\mathrm{du}_{8}$-a ud-15-kam

$m u{ }^{\mathrm{d}} \dot{e} r-r a-i-m i-t i$ lugal

4 urudu ur-mah-gal-gal

é-AN-nir-ra mu-na-dím

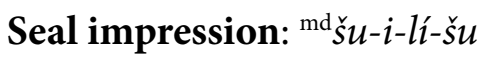

Obv.

1 Rēštum daughter of Ur-Utu

Šū-ilīšu

son of Erra-muballit.

took her for wife

5 he swore in the name of the king

he has loosened her 'belt of virginity'

the house, the field and the possessions,

as much as [they may be]

they shared like equals.

If in future,

10 Rēštum to Šū-ilišu, her husband

says: you are not my husband

she will weigh out $1 / 2$ mina of silver

and if $̌ \bar{u}$-ilī̌su

to his wife

Rev.

15 says: you are not my wife

he will weigh out $1 / 2$ mina of silver

They swore in the name of the king.

Witnesses:

Nabi-Sîn son of Nabi-ilī̌su

Atanahson of Nabi-ilišu

Aduba son of Warad-Enlila 


\section{Sîn-kīma-ilìya son of Sîn-muballit}

Adda-waqar son of ... -li-waqar

Ammanum [the] singer

\section{Sîn-iddinaššu son of Labišu}

Fifteenth day of November

year king Erra-imittī

4 large copper lions

he fashioned on the Ziggurat.

Seal impression: Šū-ilǐšu

(Al-Shamari \& Al-Jalili, 2020).

This legal document is signed by several witnesses who thereby support the following two declarations: (1) Rēštum is a wife of Šū-ilī̌su; (2) the property is owned by both spouses equally (50/50). Then there are two additional declarations formulated as conditionals: (1) if (tukumbi) Rēštum declares that Šū-ilišsu is not her husband, then she pays $1 / 2$ mina of silver; (2) if (tukum-bi) Šù-ilišu declares that Rěštum is not his wife, then she pays $1 / 2$ mina of silver.

Marriage contracts in Aramaic have almost the same logical structure as those documents in Akkadian (Yaron, 1958), which is not surprising taking into account the fact that it is the same Babylonian legal tradition. Aramaic began to supplant Akkadian as a new legal language from the $6^{\text {th }}$ century B.C.

Many legal documents in Aramaic were excavated in Elephantine (an island on the Nile). At the same place there were excavated legal documents in Greek also, but dated later than the Aramaic ones. It shows that Greek started to supplant Aramaic as a new legal language from the $4^{\text {th }}$ century B.C.

Let us consider the marriage contract between Heraclides and Demetria, composed in 311/310 B.C. - at the time of Alexander, the satrape of Ptolemy:

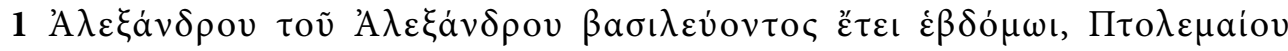

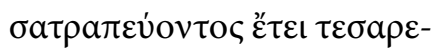

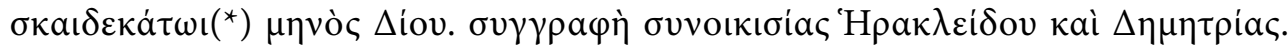
$\lambda \alpha \mu \beta a \dot{v \varepsilon \varepsilon} i^{\prime} \operatorname{\rho a\kappa } \lambda \varepsilon i \delta \eta \varsigma^{(*)}$

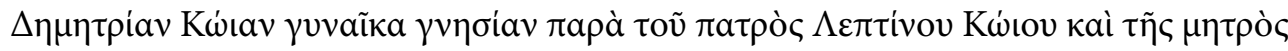
$\Phi ı \lambda \omega \tau i \delta$ oৎ $\dot{\varepsilon} \lambda \varepsilon \dot{\theta} \theta \varepsilon \rho \circ$

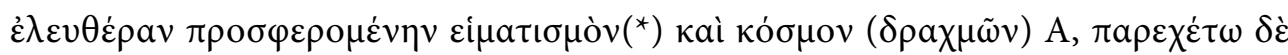

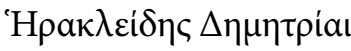

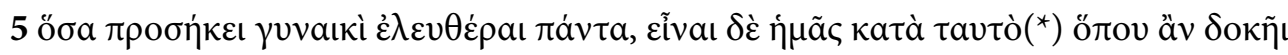

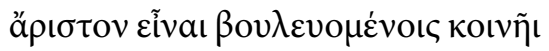




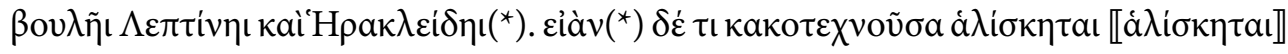

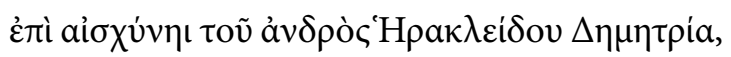

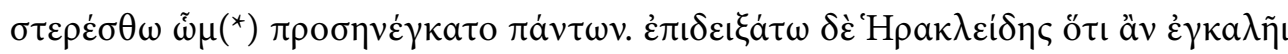

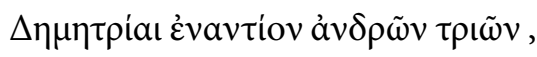

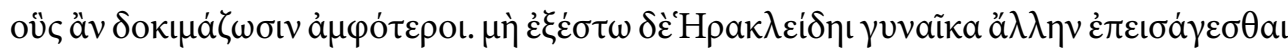
$\dot{\varepsilon} \varphi^{\prime} u ̈ \beta \rho \varepsilon เ \Delta \eta \mu \eta \tau \rho i \alpha \varsigma \mu \eta \delta \grave{\varepsilon}$

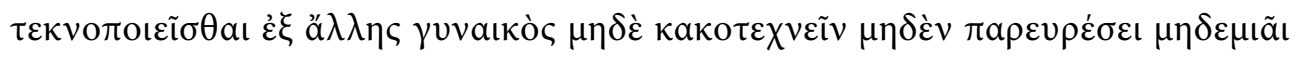

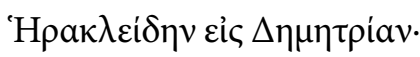

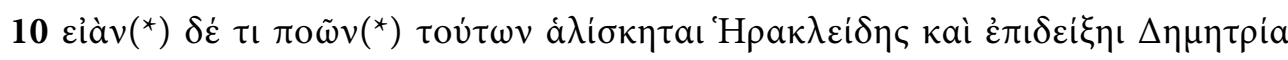

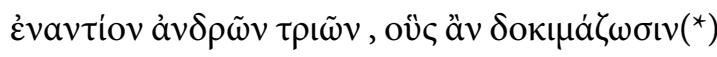

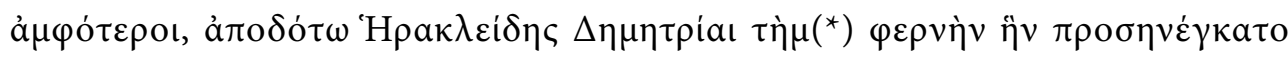

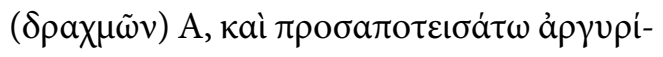

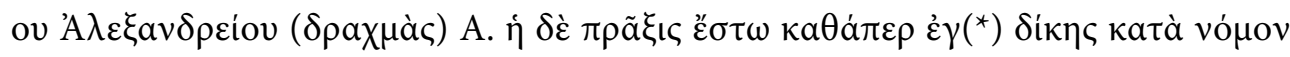

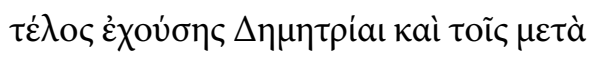

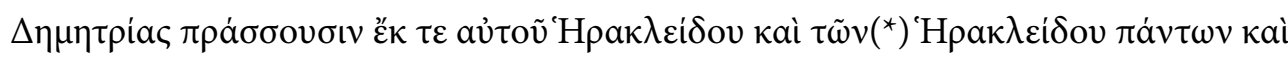

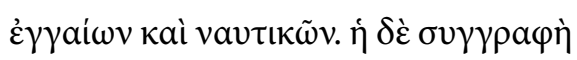

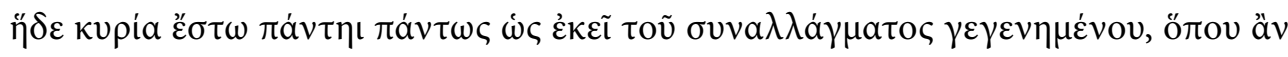

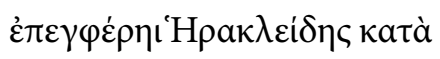

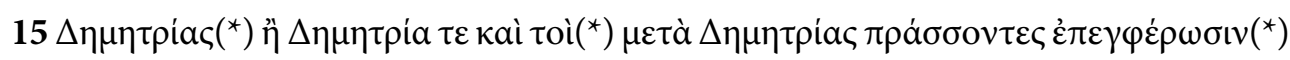

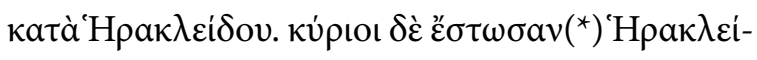

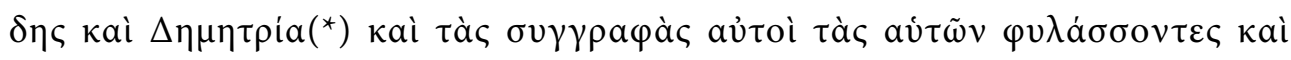

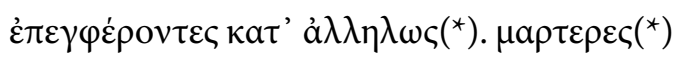

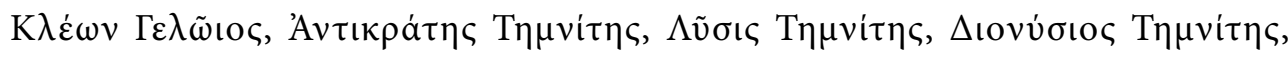

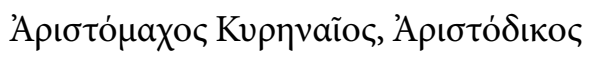

Kũıఢఢ.

(seal) (seal) (seal) (seal)

In the 7th year of the reign of Alexander son of Alexander, the 14th year of the satrapship of Ptolemy, in the month Dius. Marriage contract of Heraclides and Demetria. Heraclides takes as his lawful wife Demetria, Coan, both being freeborn, from her father Leptines, Coan, and her mother Philotis, bringing clothing and ornaments to the value of 1000 drachmae, and Heraclides shall supply to Demetria all that is proper for a freeborn wife, and we shall live together wherever it seems best to Leptines and Heraclides consulting in common.

If Demetria is discovered doing any evil to the shame of her husband Heraclides, she shall be deprived of all that she brought, but Heraclides shall prove whatever he alleges against Demetria before three men whom they both accept.

It shall not be lawful for Heraclides to bring home another wife in insult of Demetria nor to have children by another woman nor to do any evil against Demetria on any pretext. If Heraclides is discovered doing any of these things and Demetria proves it 
before three men whom they both accept, Heraclides shall give back to Demetria the dowry of 1000 drachmae which she brought and shall moreover forfeit 1000 drachmae of the silver coinage of Alexander. Demetria and those aiding Demetria to exact payment shall have the right of execution, as if derived from a legally decided action, upon the person of Heraclides and upon all the property of Heraclides both on land and on water. This contract shall be valid in every respect, wherever Heraclides may produce it against Demetria, or Demetria and those aiding Demetria to exact payment may produce it against Heraclides, as if the agreement had been made in that place.

Heraclides and Demetria shall have the right to keep the contracts severally in their own custody and to produce them against each other.

Witnesses Cleon, Gelan; Anticrates, Temnian; Lysis, Temnian; Dionysius, Temnian; Aristomachus, Cyrenaean; Aristodicus, Coan.

(Hunt \& Edgar, 1932, p. 2-3).

We see that several witnesses signed their confirmation that (1) Demetria is a wife of Heraclides, (2) Demetria has a dowry with its description, (3) the property obtained after the marriage is owned now by both spouses equally (50/50). The two additional declarations formulated as implications: (1) if Demetria is caught with another man and this fact is testimonied by at least three witnesses, then she shall be deprived of the dowry; (2) if Heraclides brings home another woman with the testimony of three witnesses or he has children by another woman with the testimony of three witnesses or he is caught with another woman with the testimony of three witnesses, then he shall give back to Demetria her dowry and shall moreover pay 1000 drachmae. To infer from the second implication, we should apply the inference rule of deleting disjunction and only then modus ponens.

Legal documents in Bactrian (one of the Eastern Middle Iranian languages) were a continuation of legal tradition in Aramaic and Greek. Furthermore, Bactrian was being written in the Greek script and it supplanted Greek as a new official language in ca. 127 A.D. in today's Afghanistan and Pakistan, according to the edict issued by Kanishka I, the emperor of Kushans (Rabatack inscription).

Let us quote one of the Bactrian marriage contracts:

\section{Document A}

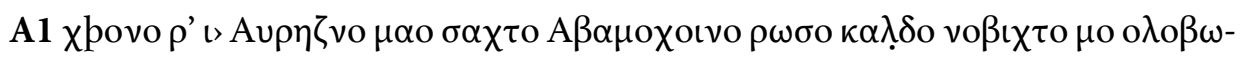

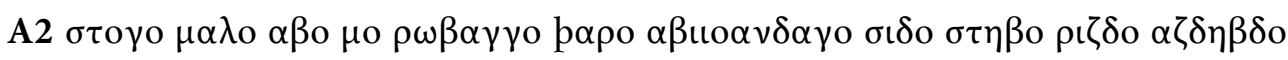
$\varepsilon \mu$ ov $\alpha v 0 \alpha \sigma \tau-$

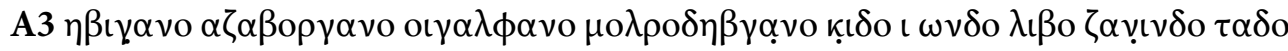
$\alpha \beta о \mu \alpha \sigma \kappa o$.

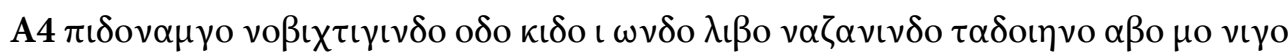
$\lambda \iota \sigma \tau о \beta \alpha \rho \circ \kappa !-$ 


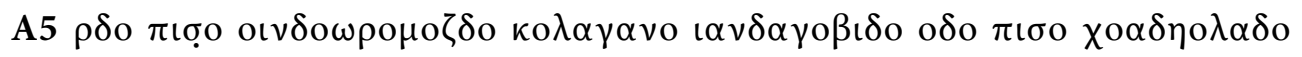

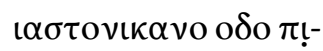

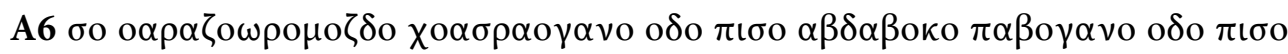
$\alpha \sigma \pi \alpha \lambda$ онро

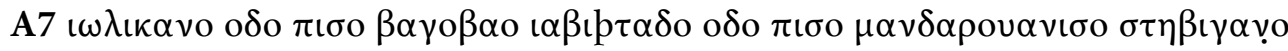

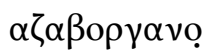

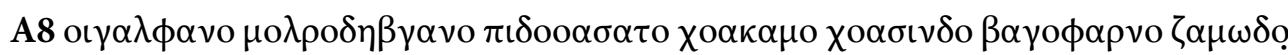
$\pi \mathrm{o \rho} \mathrm{0}$

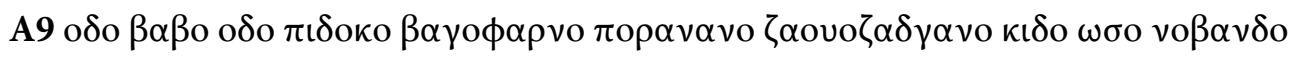
vเvסоко เ $\omega$ -

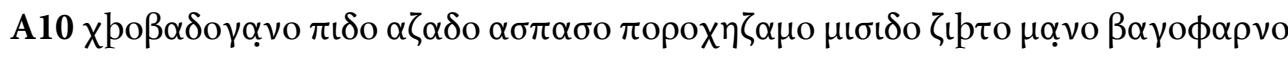
$\alpha \sigma \alpha \phi \alpha \gamma o$

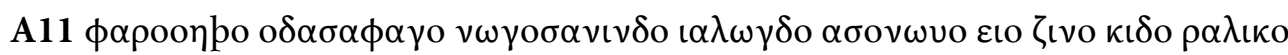
$v \alpha \mu \rho o \phi \alpha \rho-$

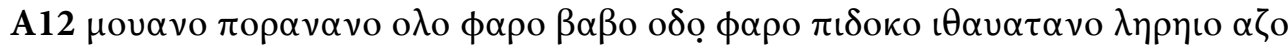
$\beta \alpha \gamma о \phi \alpha \rho v 0$

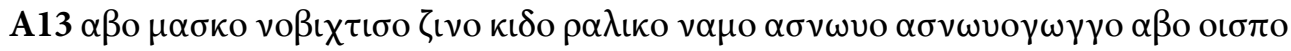
$\alpha \sigma \tau o$ ọı $\delta$ ọ $\mu-$

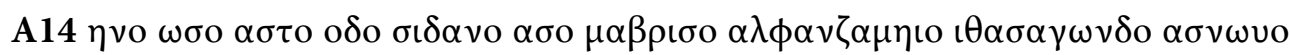
$\pi \mathrm{o} \rho \delta \mathrm{o} \alpha \beta \mathrm{o}$

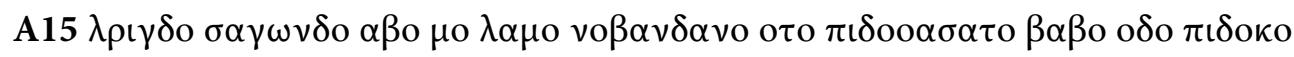
$\alpha \gamma \gamma \iota \tau \iota \delta$ o $\alpha \mu \alpha \chi^{-}$

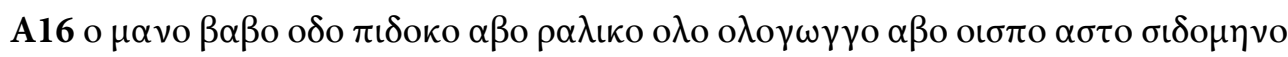
$\omega \sigma o \alpha \sigma \tau-$

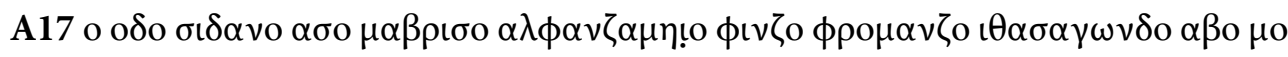
$\lambda \alpha \mu \mathrm{o} v \mathrm{o} \beta \alpha-$

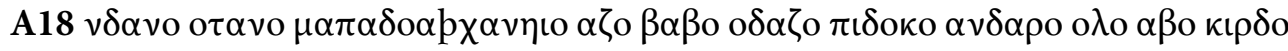

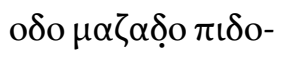

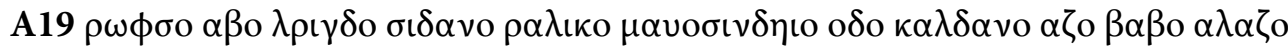
$\pi \mathrm{\iota} \delta$ око $\alpha v \delta \alpha \rho$ o

A20 o $\tau \alpha \delta \alpha v 0$

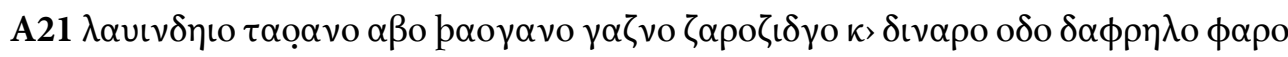
$\pi \alpha \delta \alpha \rho \lambda \mathrm{o}^{-}$

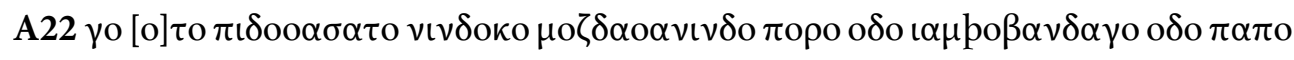

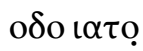

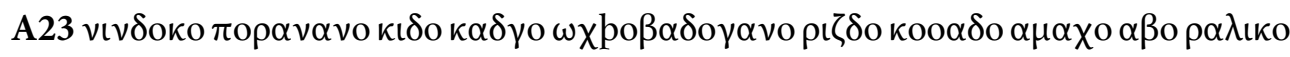
$\chi \circ \alpha \delta$ ○

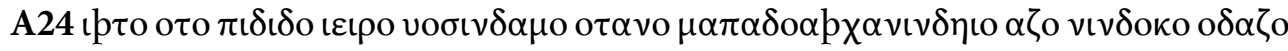
เ $\alpha \mu$ po- 


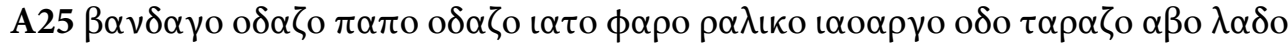

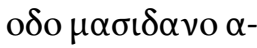

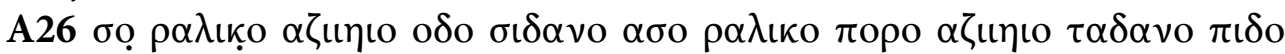

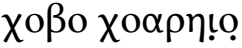

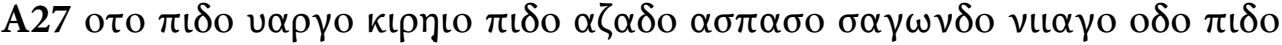

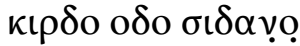

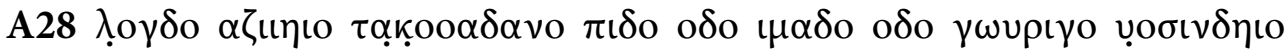
$\alpha \beta \eta \gamma о \alpha \beta o \lambda \alpha \delta$ o $\tau \alpha \delta[$ [o]

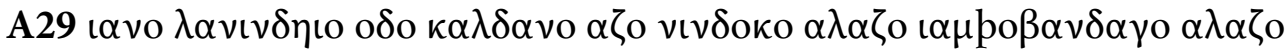
$\pi \alpha \pi$ o $\alpha \lambda \alpha \zeta$ о เ $\alpha \tau$ o oı $\alpha$ -

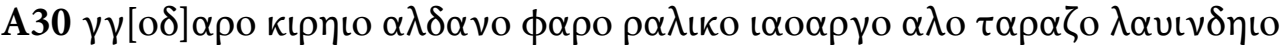
o $\delta \alpha \lambda \delta$ o $t \theta \alpha \chi 0 \alpha v ! v \emptyset \delta-$

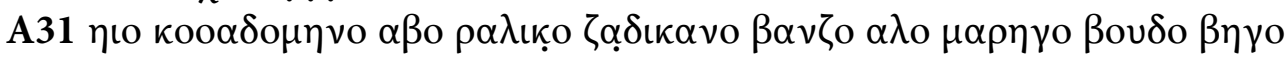
$\pi\llcorner\delta$ o $\alpha \zeta \alpha \delta$ o $\alpha \sigma \pi \alpha \sigma o$

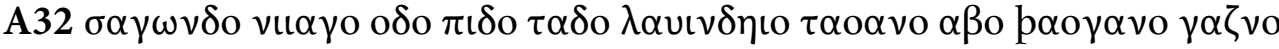

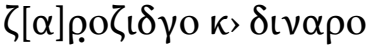

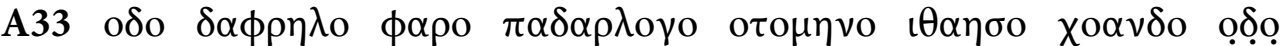

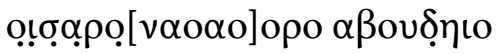

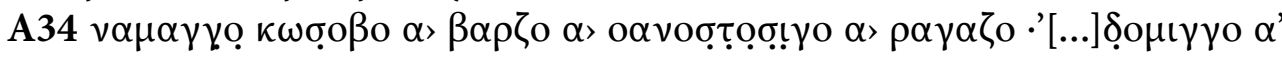
$\lambda \mathrm{l}-$

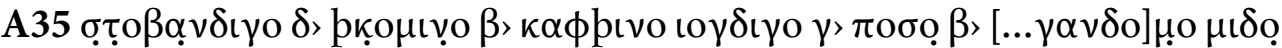
$\gamma$ '>

\section{Document A}

(It was) the year 110, the month Ahrezhn, the day Abamukhwin having elapsed, when this marriage contract was written ${ }^{2}$ here in the borough of the city of Rob which is called Steb, with the cognizance of these ${ }^{3}$ freemen of Asteb, the witnesses (and) those who have impressed (their) seals (upon it), who witness the present document and ${ }^{4}$ (whose) signatures are written hereupon - and those who do not witness the present document have put (their signatures) on the other manuscript $-{ }^{5}$ (namely) in the presence of Wind-ormuzd Kulagan the chief of the district, and in the presence of Khwadew-lad Yastunikan, and in the presence of Waraz-ormuzd Khwas-rawgan, and in the presence of Abdabuk Pabugan, and in the presence of Aspal-mir ${ }^{7}$ Yolikan, and in the presence of Bag-bandag the master craftsman, and also in the presence of the other freemen of Steb, ${ }^{8}$ the witnesses (and) those who have impressed (their) seals (upon the documents). (Then this) declaration was freely (and) willingly made (by me), Bag-farn, son of Zamod, ' and (by us), Bab and Piduk the legitimate sons of Bag-farn, who now serve with Ninduk ${ }^{10} \mathrm{Okhsh}$-badugan in free service.

Now: there has been requested by me, Bag-farn, from you, ${ }^{11} \mathrm{Far}-w e s h$, and from you, Nog-sanind, this woman whose name (is) Ralik (as) a fully privileged daughter-in-law, ${ }^{12}$ (as) a wife for these (my) sons, Bab and Piduk, so that I, Bag-farn, may treat ${ }^{13}$ the woman described herein, whose name (is) Ralik, (as) a daughter-in-law (to be treated) 
like a daughter-in-law, in every home which we ${ }^{14}$ now have and also which we may acquire in the future, as (one) ought to treat a daughter-in-law, ${ }^{15}$ as (is) the established custom in the land.

And a declaration was made (by us), Bab and Piduk. We have received ${ }^{16}$ Ralik - I, Bab, and (I), Piduk - (as) a wife (to be treated) like a wife in every home which we now have ${ }^{17}$ and also which we may acquire in the future, (as) a lady possessing authority, as (is) the established custom in the land. ${ }^{18} \mathrm{And} \mathrm{I}, \mathrm{Bab}$, and I, Piduk, shall not have the right to make another (woman our) wife, nor ${ }^{19}$ to keep a free (woman as a) concubine, to whom Ralik should not agree; and if I, Bab, or I, Piduk,

${ }^{20}$ should make another (woman our) wife, or keep a free (woman as a) concubine, to whom Ralik should not agree, then ${ }^{21}$ (we) shall give a fine to the royal treasury of twenty dinars of struck gold and the same to the opposite party.

${ }^{22}$ And a declaration was made (by us), Ninduk son of Muzda-wanind, and Yamshbandag and Pap and Yat, ${ }^{23}$ the sons of Ninduk, whose house is called Okhshbadugan, that we ourselves have requested Ralik, ${ }^{24}$ and in this matter we are in agreement, and (we) shall not have the right - I, Ninduk, and I, Yamsh $-{ }^{25}$ bandag, and I, Pap, and I, Yat - to assign duties and tasks to Ralik, nor (to) whatever (child) ${ }^{26}$ may be born from Ralik. And whatever son may be born from Ralik, then she may have (him) for her own, ${ }^{27}$ and may put (him) for hire in free service as (his) grandfather and father did; and whatever ${ }^{28}$ daughter may be born, then in as much as the father and the mother and the family may agree to give (her) away, then ${ }^{29}$ (we) shall grant (their) wish. And if I, Ninduk, or I, Yamsh-bandag, or I, Pap, or I, Yat, ${ }^{30}$ should do otherwise, or (if we) should assign duties or tasks to Ralik, or (if we) should claim thus, ${ }^{31}$ with reference to Ralik's progeny, that (the child) is our slave-girl or slave rather than in free service ${ }^{32}$ like (its) grandfather and father, then (we) shall give a fine to the royal treasury of twenty dinars of struck gold ${ }^{33}$ and the same to the opposite party, and so too our claim and argument shall be [inva]lid.

${ }^{34}$ The dowry (consists of) one blanket, one pillow, one ..., ... cloak(s), ... one ..., ${ }^{35}$ four bracelets, two ..., three pairs of shoes, two sheep, ... three measures of [wheat]. ${ }^{36} \ldots$

(Sims-Williams, 2000, pp. 32-35).

In this document, several witnesses signed the declaration that (1) Ralik is a wife of two brothers, Bab and Piduk; (2) accordingly, she became a daughter-in-law of Bag-farn, the father of these brothers; (3) she has a dowry with an appropriate description. The two additional declarations formulated as conditional statements: (1) if ( $\kappa \alpha \lambda \delta \alpha v o$ ) Bab or ( $\alpha \lambda \alpha \zeta o$ ) Piduk make another woman their wife or $\left(\alpha \lambda \alpha \zeta_{0}\right)$ they keep a free woman as their concubine, to whom Ralik should not agree, then they shall give a penalty (of twenty dinars of struck

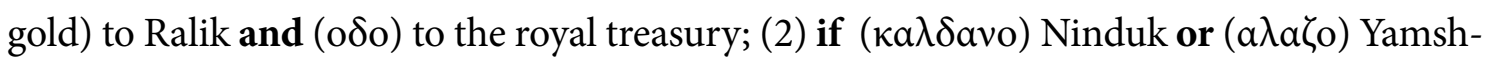


bandag or ( $\left.\alpha \lambda \alpha \zeta_{0}\right)$ Pap or ( $\left.\alpha \lambda \alpha \zeta_{0}\right)$ Yat assign duties or tasks to Ralik or ( $\alpha \lambda \alpha \zeta_{0}$ ) to the child who may be born from Ralik, then they shall give a penalty (of twenty dinars of struck

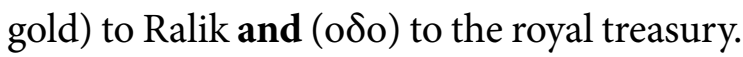

Thus, we see that marriage contracts in Akkadian, Aramaic, Greek, and Bactrian were composed within one and the same legal hermeneutics, existing for more than two thousand years at the time of the Bactrian contracts and well traced retrospectively. In marriage contracts there were one main declarative and a series of additional declarations formulated as implications and all these declaratives were confirmed by several seals of witnesses. In the trial records (transcripts) of Sumerian-Akkadian legal tradition continuing in Hellenistic and partly Hellenized states of Central and South Asia, we find already explicit and logically correct applications of different logical inference rules including modus ponens, modus tollens, and many others (Schumann, 2019, 2020). Meanwhile, these trial records are free from rhetoric tropes and logical fallacies and contain only a purely logical argumentation based on the usage of propositional logic.

\section{Conclusions}

So, the logical competence consists of the methods of implementing logical knowledge that are correct from the standpoint of logical norms and it is not our natural (innate) ability. These methods have different historical forms and can be found in the texts of some early states. Moreover, the earliest examples of perfect logical competence are found only in the documents of Mesopotamia, starting with legal documents and business correspondence of the Akkadian period (since the $24^{\text {th }}$ century B.C.). By the time of the appearance of Aristotle's treatises on logic in the $4^{\text {th }}$ century B.C. there was already a long history of the perfect logical competence within the Mesopotamian legal hermeneutics expanded later through Hellenistic states. The analysis of various forms of manifestation of this competence allows us to find out the nature of logical knowledge in its practical applications. 


\section{References}

Adamatzky, A. (ed.), (2017). Advances in Unconventional Computing. Springer International Publishing.

Adamatzky, A. (2007). Physarum machine: implementation of a Kolmogorov-Uspensky machine on a biological substrate. Parallel Processing Letters, 17(4), 455-467.

Adamatzky, A., Mayne, R. (2015). Actin automata: Phenomenology and localizations. International Journal of Bifurcation and Chaos, 25(2).

https://doi.org/10.1142/S0218127415500303

Adamatzky, A., Schubert, T. (2014). Slime mold microfluidic logical gates. Materials Today, 17(2), 86-91.

Al'churron, K.E., Bulygin, Ye.V. (2013). "Normativnyye sistemy" i drugiye raboty po filosofi prava i logike norm [«Нормативные системы» и другие работы по философии права и логике норм].

Alonso-Sanz, R., Adamatzky, A. (2016). Actin automata with memory. International Journal of Bifurcation and Chaos, 26(1).

Al-Shamari, M. Kh. J., Al-Jalili, M. (2020). Two Old Babylonian Marriage Contracts from Isin. Iraq, 82, 125-137.

Arnauld, A., Nicole, P. (1662/1992). La logique ou l’Art de penser. Gallimard.

Baker, G.S. (2020). Critical Thinking. A profound handbook to improve your memory and logical skills, level up your decision making and problem solving. Sannainvest Ltd.

Bonabeau, E., Dorigo, M., Theraulaz, G. (1999). Swarm Intelligence: From Natural to Artificial Systems. Oxford University Press.

Byosiere, S.-E., Chouinard, P. A., Howell, T. J., Bennett, P. C. (2020). Illusion susceptibility in domestic dogs. Ethology, 126(10), 949-965.

Chelpanov, G. (1917). Uchebnik logiki [Учебник логики] (9 $9^{\text {th }}$ edition).

Chen, J., Hong, H., Stein, J. C. (2001). Forecasting crashes: trading volume, past returns, and conditional skewness in stock prices. Journal of Financial Economics, 61(3), 345-381.

Church, A. (1996). Introduction to Mathematical Logic. Princeton University Press.

Clegg, I. L. K. (2018). Cognitive bias in zoo animals: An optimistic outlook for welfare assessment. Animals, 8(7). https://doi.org/10.3390/ani8070104 
Clegg, I. L., Rödel, H. G., Delfour, F. (2017). Bottlenose dolphins engaging in more social affiliative behaviour judge ambiguous cues more optimistically. Behavioural Brain Research, 322, 115-122.

Cohen. J. (1992). An Essay on Belief and Acceptance. Clarendon Press.

Copi, I. M., Cohen, C., McMahon, K. (2014). Introduction to Logic (14th edition). Pearson Education Limited.

Correia, V. (2011). Biases and fallacies: The role of motivated irrationality in fallacious reasoning. Cogency: Journal of Reasoning and Argumentation, 3(1), 107-126.

Crews-Anderson, T. A. (2007). Critical Thinking and Informal Logic. Humanities-Ebooks.

Daoudi, S., Badihi, G., Buchanan-Smith, H. M. (2017). Is mixed-species living cognitively enriching? Enclosure use and welfare in two captive groups of tufted capuchins (Sapajus apella) and squirrel monkeys (Saimiri sciureus). Animal Behavior and Cognition, 4(1), 72-90.

Dorigo, M., Gambardella, L.M. (1997). Ant colonies for the travelling salesman problem. Biosystems, 43(2), 73-81.

Eemeren, F. van, Grootendorst, R., Blair, A., Willard, C. A. (eds.), (1986). Argumentation. Foris Publications.

Eysenck, M., Mogg, K., May, J., Richards, A., Mathews, A. (1991). Bias in interpretation of ambiguous sentences related to threat in anxiety. Journal of abnormal psychology, 100(2), 144-150.

Fackler, O.T., Grosse, R. (2008). Cell motility through plasma membrane blebbing. Journal of Cell Biology, 181, 879-884.

Frege, G. (1918/1919). Der Gedanke. Eine logische Untersuchung. In Beiträge zur Philosophie des deutschen Idealismus. Band 1 (pp. 58-77). Stenger.

Frege, G. (1934). Grundlagen der Arithmetik. Marcus.

Getmanova A.D. (2011). Uchebnik logiki [Учебник логики] (8 ${ }^{\text {th }}$ edition). КНОРУС.

Gilovich, T., Griffin, D., Kahneman, D. (eds.), (2002). Heuristics and Biases: The Psychology of Intuitive Judgment. Cambridge University Press.

Gödel K. (1931). Über formal unentscheidbare Sätze der Principia Mathematica und verwandter Systeme, I. Monatshefte für Mathematik und Physik, 38(1), 173-198.

Goldberg, J., von Nitzch, R. (2001). Behavioural Finance. John Wiley \& Sons. 
Greengus, S. (1969). The Old Babylonian Marriage Contract. Journal of the American Oriental Society, 89(3), 505-532.

Heaton, J. B. (2002). Managerial optimism and corporate finance. Financial Management, $31(2), 33-45$.

Heymans, G. (1905). Die Gesetze und Elemente des wissenschaftlichen Denkens. Ein Lehrbuch der Erkenntnistheorie in Grundzügen. Barth.

Hilbert, D., Ackermann, W. (1949). Grundzüge der theoretischen Logik (Dritte, verbesserte Auflage). Springer-Verlag.

Hilbert, D., Bernays, P. (1968). Grundlagen der Mathematik. Band 1 (Zweite Auflage). Springer-Verlag.

Howard, S. R., Avarguès-Weber, A., Garcia, J. E., Stuart-Fox, D., Dyer, A. G. (2017). Perception of contextual size illusions by honeybees in restricted and unrestricted viewing conditions. Proceedings of the Royal Society B: Biological Sciences, 284(1867), 20172278.

Huang, X., MacEvoy, S. P., Paradiso, M. A. (2002). Perception of brightness and brightness illusions in the macaque monkey. Journal of Neuroscience, 22(21), 9618-9625.

Hunt, A. S., Edgar, C. C. (1932). Select Papyri. Volume I: Private Documents. Loeb Classical Library 266. Harvard University Press.

Johnson, R., Blair, J. (1983). Logical Self-defense. McGraw-Hill.

Jones, J. D., Adamatzky, A. (2010). Towards Physarum binary adders. Biosystems, 101(1), 51-58.

Jones, J.D. (2015). Towards lateral inhibition and collective perception in unorganised non-neural systems. In K. Pancerz, E. Zaitseva (eds.), Computational Intelligence, Medicine and Biology: Selected Links (pp. 103-122). Springer.

Kelley, D. (2014). The Art of Reasoning: An Introduction to Logic and Critical Thinking (4 ${ }^{\text {th }}$ edition). W. W. Norton \& Company, Inc.

Kern, L. H., Mirels, H. L., Hinshaw, V. G. (1983). Scientists' understanding of propositional logic: An experimental investigation. Social Studies of Science, 13(1), 131-146.

Kunda, Z. (1990). The Case for Motivated Reasoning. Psychological Bulletin, 108(3), 480-498.

Mayne, R., Adamatzky, A. (2015). Slime mould foraging behaviour as optically coupled logical operations. International Journal of General Systems, 44(3), 305-313. 
Mortari, C.A. (2001). Introdução à Lógica. Editora UNESP: Imprensa Oficial do Estado.

Ozbakir, L., Baykasoglu, A., Tapkan, P. (2010). Bees algorithm for generalized assignment problem. Applied Mathematics and Computation, 215(11), 3782-3795.

Parrish, A., Brosnan, S., Beran, M. (2015). Do you see what I see? A comparative investigation of the Delboeuf illusion in humans (Homo sapiens), rhesus monkeys (Macaca mulatta), and capuchin monkeys (Cebus apella). Journal of experimental psychology. Animal learning and cognition, 41. https://doi.org/10.1037/xan0000078

Pepperberg, I. M., Vicinay, J., Cavanagh, P. (2008). Processing of the Müller-Lyer illusion by a grey parrot (Psittacus erithacus). Perception, 37(5), 765-781.

Pollard, T.D., Borisy, G.G. (2003). Cellular motility driven by assembly and disassembly of actin filaments. Cell, 112, 453-465.

Povarnin, S. I. (1916). Logika [Логика].

Robinson, E., Roiser, J. (2016). Affective Biases in Humans and Animals. In T. W. Robbins, B. J. Sahakian (eds.), Translational Neuropsychopharmacology (pp. 263-286). Springer International Publishing.

Roelofs, S., Boleij, H., Nordquist, R. E., van der Staay, F. J. (2016). Making decisions under ambiguity: Judgment bias tasks for assessing emotional state in animals. Frontiers in Behavioral Neuroscience, 10, 119. https://doi.org/10.3389/fnbeh.2016.00119

Sakiyama, T., Gunji, Y.-P. (2013). The Müller-Lyer illusion in ant foraging. PLOS ONE, 12(8), 1-12.

Santacà, M., Miletto Petrazzini, M. E., Agrillo, C., Wilkinson, A. (2019). Can reptiles perceive visual illusions? Delboeuf illusion in red-footed tortoise (Chelonoidis carbonaria) and bearded dragon (Pogona vitticeps). Journal of Comparative Psychology, 133. https://doi.org/10.1037/com0000176

Schumann, A. (ed.), (2020). Swarm Intelligence: From Social Bacteria to Humans. CRC Press, Taylor \& Francis Group.

Schumann, A. (2019). Behaviourism in studying swarms: logical models of sensing and motoring. Springer International Publishing.

Schumann, A. (2018). Decidable and undecidable arithmetic functions in actin filament networks. Journal of Physics D - Applied Physics, 51(3), 034005.

Schumann, A. (2019). Did the Neo-Babylonians Construct a Symbolic Logic for Legal Proceedings? Journal of Applied Logics - IfCoLog Journal of Logics and their Applications, 6(1), 31-82. 
Schumann, A. (2020). Legal argumentation in Mesopotamia since Ur III. Journal of Argumentation in Context, 9(2), 126-154.

Schumann, A. (2017). On arithmetic functions in actin filament networks. In 10th EAI International Conference on Bio-inspired Information and Communications Technologies (formerly BIONETICS), ACM. https://doi.org/10.4108/eai.22-32017.152402

Schumann, A. (2015). p-adic valued logical calculi in simulations of the slime mould behaviour. Journal of Applied Non-Classical Logics, 25(2), 125-139.

Schumann, A. (2016). Toward a computational model of actin filament networks. In Proceedings of the 9th International Joint Conference on Biomedical Engineering Systems and Technologies (BIOSTEC 2016) - Volume 4: BIOSIGNALS, Rome, Italy, February 21-23, 2016 (pp. 290-297). https://doi.org/10.5220/0005828902900297 .

Schumann, A., Kuznetsov, A. V. (2018). Foundations of Mathematics under Neuroscience Conditions of Lateral Inhibition and Lateral Activation. International Journal of Parallel, Emergent and Distributed Systems, 33(3), 237-256.

Schumann, A., Pancerz, K. (2019). High-level models of unconventional computations. A case of plasmodium. Springer International Publishing.

Shirakawa, T., Gunji, Y.-P., Sato, H., Tsubakino, H. (2020). Diversity in the Chemotactic Behavior of Physarum Plasmodium Induced by Bi-modal Stimuli. International Journal of Unconventional Computing, 15(4), 275-285.

Shirakawa, T., Sato, H., Ishiguro, S. (2015). Constrcution of living cellular automata using the Physarum polycephalum. International Journal of General Systems, 44, 292-304.

Shirakawa, T., Yokoyama, K., Yamachiyo, M., Gunji, Y.P., Miyake, Y. (2012). Multi-scaled adaptability in motility and pattern formation of the Physarum plasmodium. International Journal of Bio-Inspired Computation, 4, 131-138.

Siccardi, S., and Adamatzky, A. (2015). Actin quantum automata: Communication and computation in molecular networks. Nano Communication Networks, 6(1), 15-27.

Siccardi, S., and Adamatzky, A. (2016). Quantum actin automata and three-valued logics. IEEE Journal on Emerging and Selected Topics in Circuits and Systems, 6(1), 53-61.

Siccardi, S., Tuszynski, J. A., Adamatzky, A. (2016). Boolean gates on actin filaments. Physics Letters A, 380 (1), 88-97.

Sigwart, Ch. von (1895). Logic. Vol. I: the Judgment, Concept, and Inference (2nd edition, translated by Helen Bendy). Swan Sonnenschein \& co; Macmillan \& co. 
Sims-Williams, N. (2000). Bactrian Documents from Northern Afghanistan. Vol. I: Legal and Economic Documents. Oxford University Press.

Sjoberg, E. (2017). Logical fallacies in animal model research. Behavioral and brain functions, 13(1), 3 .

Spruijt, B. M., van den Bos, R., Pijlman, F. T. (2001). A concept of welfare based on reward evaluating mechanisms in the brain: anticipatory behaviour as an indicator for the state of reward systems. Applied Animal Behaviour Science, 72(2), 145-171.

Stenning, K., van Lambalgen, M. (2011). Reasoning, logic, and psychology. Wiley Interdisciplinary Reviews. Cognitive Science, 2(5), 555-567.

Stenning, K., van Lambalgen, M. (2008). Human reasoning and cognitive science. MIT Press.

Swetz, F. J. (2003). Leibniz, the Yijing, and the Religious Conversion of the Chinese. Mathematics Magazine, 76(4), 276-291.

Talisse, R., Aikin, S. (2004). Two Forms of the Straw Man. Argumentation, 20(3), 345-352.

Tverky A., Kahneman D. (1974). Judgment under uncertainty: Heuristics and biases. Science, $185,1124-1131$.

Tversky, A., Kahneman, D. (2008). Extensional Versus Intuitive Reasoning: The Conjunction Fallacy in Probability Judgment. In J. E. Adler, L. J. Rips (eds.), Reasoning: Studies of Human Inference and its Foundations (pp. 114-135). Cambridge University Press.

Van Haastert, P.J., Devreotes, P.N. (2004). Chemotaxis: signalling the way forward. Nature Reviews Molecular Cell Biology, 5, 626-634.

Vinogradov, S. N., Kuz'min, A. F. (1954). Logika [Логика] (8th edition). Государственное учебно-педагогическое издательство Министерства просвещения РСФСР.

Walton, D. (1989). Informal Logic. Cambridge University Press.

Whiting, J. G., de Lacy Costello, B. P., Adamatzky, A. (2014). Slime mould logic gates based on frequency changes of electrical potential oscillation. Biosystems, 124, 21-25.

Wright, W. F., Bower, G. H. (1992). Mood effects on subjective probability assessment. Organizational Behavior and Human Decision Processes, 52 (2), 276-291.

Yaron, R. (1958). Aramaic Marriage Contracts from Elephantine. Journal of Semitic Studies, 3(1), 1-39.

Culbertson, L. E. (2009). Dispute Resolution in the Provincial Courts of the Third Dynasty of Ur. A dissertation submitted in partial fulfilment of the requirements for the degree of Doctor of Philosophy (Near Eastern Studies) in the University of Michigan. 